\title{
Long-Term Treatment of Sulphonylurea-Treated Diabetics with the $\alpha$-Glucosidase Inhibitor Bay g 5421 (Acarbose)
}

Dear Sir,

A lowered postprandial rise of blood glucose following the ingestion of an $\alpha$-glucosidase inhibitor (Acarbose, Bay g 5421, [1]) has been described in patients with diabetes mellitus [2-6]. The drug appears to be less effective, however, following its prolonged administration in patients with Type 2 diabetes [3]. This observation seems to be confirmed by results recently obtained in 13 Type 2 diabetics (seven males, six females, aged $54-77$ years, duration of diabetes: $8 \pm 6(\mathrm{SD})$ years), who in addition to sulphonylurea administration were treated for two consecutive periods of 4 weeks with either the glucosidase inhibitor $(300 \mathrm{mg} /$ day), or placebo, in a double blind cross-over study.

Basal blood glucose concentrations were lower $(p<0.05)$ after 2,3 , and 4 weeks of treatment with Bay g 5421 when compared with placebo, and the postprandial rise of blood glucose following a standard breakfast was diminished $(p<0.05)$ after the first $(\Delta=$ $1.6=1.1$ versus $2.1 \pm 1.4 \mathrm{mmol} / \mathrm{l}$ following ingestion of placebo)), and third $(\Delta=1.9 \pm 1.3$ versus $2.8 \pm 1.6 \mathrm{mmol} / \mathrm{l})$ week of therapy. No significant difference was observed in the postprandial rise of blood glucose at the end of the second $(\Delta=1.7 \pm 1.5$ versus $2.6 \pm 1.6 \mathrm{mmol} / \mathrm{l})$ and fourth $(\Delta=2.1 \pm 1.4$ versus $2.3 \pm$ $1.5 \mathrm{mmol} / \mathrm{l})$ week of therapy with Bay $\mathrm{g} 5421$.

Furthermore, six patients (three males, three females, age: 71 \pm 7 years) agrecd to continue treatment with the $\alpha$-glucosidase inhibitor $(300 \mathrm{mg} /$ day) for 12 months. This period of therapy was then followed by a final placebo period of 3 months. As demonstrated in Fig. 1, the postprandial rise in blood glucose in these six

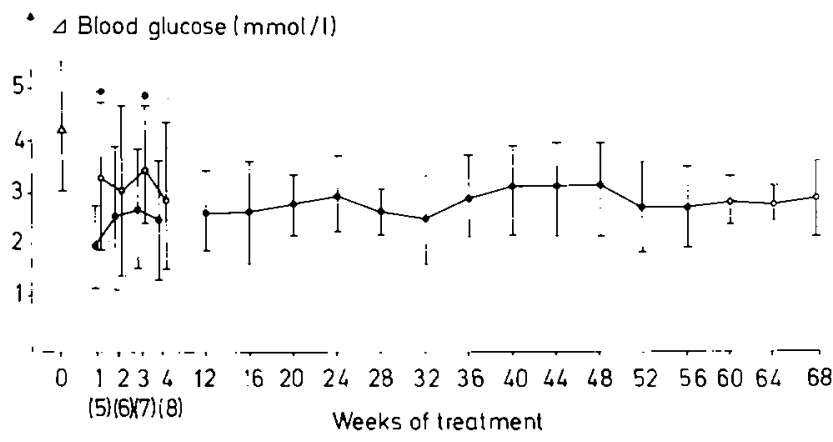

Fig. 1. Postprandial rise in blood glucose ( $\triangle$ blood glucose $(\mathrm{mmol} / \mathrm{I})$, mean $\pm \mathrm{SD})$ in six Type 2 diabctics before $(\triangle)$, and during treatment with either Bay g $5421(0)$ or placebo $(O)$ patients during the initial randomized 8 weeks trial showed a similar behaviour as described above for the whole group of 13 patients, the postprandial rise in blood glucose being lowered $(p<$ 0.05 ) by Bay g 5421 at the end of the first and third week of therapy only. During prolonged treatment with Bay g 5421, the observed postprandial rise in blood glucose was not different from the mean of postprandial rise in blood glucose seen during the initial or during the final placebo period.

No serious side-effects were seen during treatment with either placebo or with the $\alpha$-glucosidase inhibitor, but the patients on Bay g 5421 complained about flatulence. These observations cast doubt on the usefulness of this drug for long-term treatment of Type 2 diabetes, suggesting a lack of effectiveness with prolonged administration.

\section{References}

1. Schmidt DD, Frommer W, Junge B, Müller L, Wingender W, Truscheit E (1977) $\alpha$-Glucosidase inhibitors. New complex oligosaccharides of microbial origin. Naturwissenschaften 64: 535

2. Puls W, Keup U, Krause HP, Thomas G, Hoffmeister F (1977) Glucosidase inhibition. A new approach to the treatment of diabetes, obesity, and hyperlipoproteinaemia. Naturwissenschaften 64: 536

3. Vierhapper H, Bratusch-Marrain P, Waldhäusl W (1978) $\alpha$ Glucoside hydrolase inhibition in diabetes. Lancet 2: 1386

4. Walton RJ, Sherif IT, Noy GA, Alberti KGGM (1979) Improved metabolic profiles in insulin-treated diabetic patients given an alpha-glucosidehydrolase inhibitor. $\mathrm{Br}$ Med $\mathrm{J}$ 1: 220-221

5. Sachse G, Willms B (1979) Effect of the $\alpha$-glucosidase inhibitor Bay g 5421 on blood glucose control of sulphonylurea-treated diabetics and insulin-treated diabetics. Diabetologia 17: $287-290$

6. Laube H, Fouladfar M, Aubell R, Schmitz H (1980) Zur Wirkung des Glukosidasehemmers Bay g 5421 (Acarbose) auf das Blutzuckerverhalten bei adipösen Erwachsenendiabetikern. Arzneim Forsch 30: 1154-1157

H. Vierhapper

P. Bratusch-Marrain

W. Waldhäusl

I. Medizinische Universitätsklinik

Division of Clinical Endocrinology and Diabetes mellitus

A-1090 Wien, Austria

Responsible for the text: Dr. A. G. Cudworth, Department of Diabetes, Medical Unit, King George V Building (5th Floor), St. Bartholomew's Hospital, London EC1 A 7BE, England

Responsible for advertisements: L. Sicgel, B. Schultz, Kurfürstendamm 237, D-1000 Berlin 15. Springer-Verlag Berlin Heidelberg New York

Printed in Germany by aprinta, Wemding

Copyright $\mathbb{C}$ Springer-Verlag GmbII \& Co. KG, Berlin Heidelberg 1981 